\title{
Éric AunOBLE
}

Université de Genève

\section{War Spoliations and Cultural Transfers: The Case Study of Soviet Cinema (1939-1949) Foreword}

This collection of articles is one of the last achievements of the scientific project called Cinema in the Soviet Union at war, 1939-1949. This project was initiated by Valérie Pozner (CNRS, Arias THALIM) and Alexandre Sumpf (University of Strasburg, ARCHE, CERCEC) and its goal was to go way further than studies on a couple of Soviet war films uniformly quoted by authors dealing with the role of cinema during the "Great patriotic war". It meant to include in its scope documentaries, newsreels and cartoons in order to explore this crucial moment in the development of one of the most important creative cultures of film history. In addition, its task was to explore the place of the cinema in a propaganda system usually described as totalitarian and to study a pivotal period of the Soviet past about which new historiography broadened our vision. A special aim of the project was also to associate political and film history whereby research in archives of written documents and film archives must be of equal importance. Moreover, the industrial, commercial as well as cultural and social processes were to be studied as they add up to an intricate system of production, distribution and reception of imageries in a huge and multidimensional Soviet territory. Consequently, the analysis of pictures would be founded on a deeper knowledge of the contexts in which they were elaborated. This ambitious plan was supported by the French National Research Agency (ANR) for 2013-2015. For three years, it involved several researchers, both senior (Sophie Coeuré, Gabor Rittersporn, Éric Aunoble, Matthias Steinle) and junior (Thomas Chopard, Juliette Denis, Irina Tcherneva, Vanessa Voisin). 
To examine Soviet cinema not only as art but also as a social sphere, a production process, an industrial establishment, a business and as a problem of marketing and consuming images: this was the aim of an international conference held in Moscow in 2014, entitled "Soviet Film Studios at War, 1939-1949". The main focus was on the first stage of filmmaking, the production process, and more precisely on the functioning of the studios in the USSR and the territories it controlled from the immediate prewar to postwar years. The goal of the conference was to study how the Soviet structures of film production dealt with the requirements and constraints imposed by the war by focusing the study on human resources, as well as economic, financial and technological issues. The fate of various film makers, studios and of a number of projects was studied all through the war and throughout the Soviet territory (Pozner, Tcherneva et Voisin 2017).

To renew the analysis of images dealing with war atrocities was another challenge for the team. For the $70^{\text {th }}$ anniversary of the liberation of the Nazi camps, an exhibition called "Filming the War: the Soviets and the Holocaust" was set up on the basis of previously unreleased newsreels and archival documents from the former USSR. The exhibition shows the war-time film production circuit and the very real difficulties encountered by the cinematographic teams on the battlefront, particularly the severe shortage of supplies, thus shedding light on the commitment of Soviet film cameramen. The Soviets were the first to discover the massacres of civilians and the mass executions committed by the Nazis. They were also the first to meet living witnesses and to enter the extermination camps. As from the end of 1942, films were used to document an extraordinary commission of inquiry and became charges when war criminals were put on trial. They also did play a role in a general propaganda effort aimed at inciting vengeance in the population and encouraging the Allies to open a new front in the East (Pozner, Sumpf, Voisin 2015; Pozner, Voisin 2015).

In 2015, the Toulouse Film Library hosted an international conference about this last topic, accompanying a retrospective of Soviet films. The discussions on "Soviet War Propaganda on the Movie Screen, 1939-46" intended to contribute to the renewal of our understanding of the Soviet "propaganda art". The term must be seen as covering a larger field than that of political agitation and also relates to education and to the spreading among the civil population of knowledge of public hygiene, sanitary prevention, military training or civil defence duties. On the other hand, the aim was to highlight specificities of the war propaganda which directs the use of all means of communication at a unique target. In this way, the exploration of Soviet cinema relies 
on a great number of studies about the wartime mobilization of the movie industry by the anti-Nazi coalition as well as by the enemies. ${ }^{1}$

The research project team is currently working on the publication of a book under the auspices of the French Association for Research on Cinema History (AFRHC). It will sum up some of the achievements of the project. It will also address a number of technical aspects about which academic knowledge is still weak. Soviet movie technique evolved considerably during the war on the one hand due to the US Lendlease programme, on the other hand thanks to seizures in defeated countries (this is especially true concerning the introduction of colour motion picture film). The book will also deal with the building up of cinema archives or with the export of Soviet movies during the war and immediately afterwards.

Finally, this special issue of Connexe dedicated to "War Spoliations and Cultural Transfers: The Case Study of Soviet Cinema (1939-1949)" aims to set the history of Soviet cinema during the Second World War in the context of European history and to highlight the issues of transfers and seizures which are better known when concerning other objects, as archives or works of art.

Sophie Cœuré, a renowned expert in this field, presents a state of the art based on the historiographical advances related to the films that were looted during World War Two and put it in the context of a broader history of cultural goods during war and post-war periods. She sheds light on the place of films and cinema industry in Nazi lootings and pillages, before trying to follow the fate of plundered film heritage during a long Cold War.

The destiny of particular movies through this very troubled period and under various flags is tackled by Christina Tanis, Juliette Denis and Irina Tcherneva. Concerning the question of seizures and the Soviet distribution policy of trophy films, Christina Tanis presents us with some remarkable archival documents showing how the 1942 German documentary about the Nazi expedition to Tibet became a Soviet film in 1948 denouncing local theocracy and British imperialism. It teaches a lot concerning the internal decisions about releases, cut-offs and dubbing.

On the other side of the Cold War front, Juliette Denis and Irina Tcherneva trace the tribulations of "Red Mist", an anti-Soviet documentary film released in Latvia under Nazi rule which underwent significant changes after the war for the purpose of the nationalist Latvian diaspora in the United States in order to comply with the American anti-communist narrative. Even though the most evident signs of Nazi

1 For a thorough account of the conference, see Tcherneva 2016. Papers from the conference and also about propaganda in occupied territories will be published in a special issue of the journal Conserveries Mémorielles (https://cm.revues.org/) under the supervision of Irina Tcherneva. 
propaganda had disappeared, the core representation of a pure nation attacked by barbarians remained, based on the same deceitful use of documentary images.

If movies could switch from one country to another, it frequently reflected the peregrinations of movies makers. This aspect, concerning Poland during the war, is studied by Éric Aunoble. The country was first erased by the Molotov-Ribbentropp pact, then partially annexed by the Soviet Union as a part of the Ukrainian Republic before becoming a forced "independent" ally after 1941. Local actors, Soviet directors but also a Polish screenplay writer had to deal with that volatile situation and produced constantly changing representations of Poland.

In Western democracies, the challenge from June 1941 was to change the official image of the Soviet Union having presented it for already two decades as a red hell. Jeremy Hicks tells us how British officials tried to propagandise a positive image of their new eastern ally without giving ground to communist agitprop. Coping with the Soviet embassy to "steal the Thunder of the Left", Churchill's government could nevertheless not avoid the images of Soviet people at war to impress the public in Great Britain and nurture the desire for social change.

In contributing to the development of the historiography of war spoliation, we hope to shed light on some unknown aspects of cultural exchanges in Europe during the Second World War and to confirm the value of cinema for historical knowledge.

\section{Renvois bibliographiques}

Pozner Valérie, Alexandre Sumpf (dir.), Catalogue de l'exposition "Filmer la guerre: les Soviétiques face à la Shoah, 1941-1946", Paris, Mémorial de la Shoah, 2015.

Pozner Valérie, Alexandre Sumpf, Vanessa Voisin, "Que faire des images soviétiques de la Shoah?”, 1895. Mille huit cent quatre-vingt-quinze, 2015, n76, online document, $<\mathrm{http}: / / 1895$. revues.org/5007>, accessed 21.05.2017.

Pozner Valérie, Irina Tcherneva, Vanessa Voisin (dir.), Perežit'vojnu. Kinoindustrija v SSSR, 1939 - 1949 gody, Moscou: ROSSPEN, 2017 (to be published).

Tcherneva Irina, "Review: 'International Colloquium Soviet War Propaganda on the Movie Screen, 1939-1946 / La propagande de guerre soviétique à l'écran, 1939-1946"', Apparatus. Film, Media and Digital Cultures in Central and Eastern Europe, 2016, n 2-3, online document, <http://www.apparatusjournal.net/index.php/apparatus/article/ view/9/76>, accessed 21.05.2017. 